\title{
CARELESS CHOICES, DREADFUL CONSEQUENCES: A COMPARATIVE STUDY OF W.W. JACOBS' THE MONKEY'S PAW AND RICHARD MATHESON'S BUTTON, BUTTON
}

\author{
Ratna Asmarani \\ English Department, Faculty of Humanities \\ Diponegoro University, Semarang, Indonesia \\ ratna_asmarani@yahoo.com
}

\begin{abstract}
The purpose of this paper is to analyze the theme of free choices and their relation to the stated consequences embodied in the two short stories, one by W.W. Jacobs entitled The Monkey's Paw and another one by Richard Matheson entitled Button, Button. The analysis focuses on four aspects; namely, the situational triggers of the free choices, the gripping conflicts in the free choices, the ethical consequences, and the purpose of the twisted endings. The concepts borrowed to support the analysis are the concepts concerning situational choices, morality types, and ethical consequences. The research methods applied in the analysis are the combination of the library research, the textual method enriched with the relevant contexts in order to completely dig out the proposed problems The results of the discussion show that every free choice taken under whatever reason will lead to the stated consequence whether it is unbelievable or impossible. The superstitious atmosphere in The Monkey's Paw and the mysterious atmosphere in the Button, Button, all lead to the inevitability to avoid the temptation to choose resulting in the disastrous consequences.
\end{abstract}

Keywords: choices; morality types; consequences; twisted endings

\section{Introduction}

Life is basically a series of choices followed by consequences. This basic rule is surprisingly portrayed due to the unexpected results in the two short stories being compared; namely, Monkey's Paw by W.W. Jacobs and Button, Button by Richard Matheson. W.W. Jacobs (1863-1943) is a British writer and Richard Matheson (19262013) is an American writer.

The two short stories are worth being compared because both have a thrilling mixture of suspense and horror atmosphere even though the writers are from different eras and nationalities. Suspense and horror dominating the two short stories will intensify the consequences of the taken choices.
The Monkey's Paw is about a family consisting of a father, a mother, and a son which is tempted to see the magical power said to be possessed in the mummified monkey's paw given by the father's friend to be finally ended in an horror beyond imagination. Button, Button is about a family consisting of a husband and a wife in which the wife is tempted, although she has been warned that a stranger will die, by the $\$ 50.000$ reward if she pushes the button in the box sent mysteriously to their doorstep, resulting in an unexpected ending with a thoughtprovoking question. Based on the brief summary of the two short stories above, this comparative study will discuss the choices done out of careless curiosity 
that bring unexpected disastrous consequences.

This topic done comparatively has not been analyzed yet. There are several articles on Monkey's Paw by W.W. Jacobs and Button, Button by Richard Matheson, however there is no comparative article on the two short stories; thus, this comparative analysis will give a new insight concerning the two short stories. The proposed topic about the careless but free choices leading to the stated but devastating consequences as a new and challenging topic is worth being analyzed due to its uniting theme offering a new idea while broadening the analyses already done.

In order to analyze the topic mentioned above, several concepts are needed. The first concept reviewed is about choice. According to Levin and Migrom, "... real-world choices often appear to be highly situational or context-dependent. The way in which a choice is posed, the social context of the decision, the emotional state of the decision-maker, the addition of seemingly extraneous items to the choice set, and a host of other environmental factors appear to influence choice behavior" (2004: 22). They emphasize the element of situation or context surrounding the choices. In other words, a choice is not made in a vacuum, there are many factors influencing the action of choosing. The factors related to the contextual choice will help the comparative analysis.

The second concept to support the analysis is the concept of moral in relation to the choice taken. A moral theory is "a theory of how we determine right and wrong conduct" ("The Nature of Morality and Moral Theories") in which "A moral conflict occurs when objectives, values, or ideals that elicit strong reactions in a person compete" (Krosch, Figner, Elke, 2012: 224). There is a basic difference between the meaning of morality from the normative sense and from the descriptive sense. The descriptive sense of morality emphasizes the "relational nature" of morality while the normative sense does not (Gert, 2020). Both types of morality are found in one of the short stories.

Another concept needed to support the analysis is the concept which relates to the consequence. Bonde, et all (2013) state that in the Ethical Theories, there is "Consequentialist Theories, which are primarily concerned with the ethical consequences of particular actions". The Consequentialist Theories cover, among others, "The Utilitarian Approach" and "The Egoistic Approach". The Utilitarian Approach emphasizes "the greatest balance of good over harm" while The Egoistic Approach emphasizes "the greatest amount of good for him or herself" when it is related to the consequences. Thus it can be summed up that the consequence of a certain choice might be directed for the sake of others or for the sake of self. These two types of approach in making choices are reflected in the two short stories.

\section{Research method}

There are several methods used in the analysis. Library research method is used to collect supporting data and the close reading is applied to scrutinize the data. The data is analyzed using qualitative method. The literary analysis is basically based on the Textual method focusing on 
the intrinsic elements especially characters, conflict, and the plot twist in the form of Peripeteia, "when a story takes a major turn in the opposite direction" (Hill, 2017).

To enrich the Textual method, the relevant contexts are incorporated, bearing in mind Beard statement "Context refers to what goes with a text, rather than what is in it" (2001: 6). Thus it can be said that the literary analysis applies the contextual method in the form of a rich combination of textual elements and its contextual elements. The contextual elements supporting the analysis of textual elements are the relevant concept on choice, morality, and consequence. The application of these combined methods will give a thorough support to the comparative analysis of the two short stories.

\section{Results and Discussion}

The two short stories being compared contain the same theme; that is, free but careless choices that bring stated but disastrous consequences beyond imagination. The analysis will prove that in whatever situation, whether it is colored with disbelieving or a moment of being upset, once a choice taken then a consequence will automatically follow sometimes even in the form of a sudden but destructive effect. To dig the theme, the analysis will focus on several aspects; namely, The Triggers of the Careless Choices, The Conflicts Surrounding the Careless Choices, The Immediate, Natural, but Dreadful Consequences, and The Twisted Endings.

\section{The Triggers of the Careless Choices}

This section will dig out the contextual situation that gives rise to each choice done in a split second in the two short stories.

\section{The Monkey's Paw}

A brief general background of the short story entitled The Monkey's Paw by W.W. Jacobs is presented to introduce the specific situation leading to the eyewink choice. This short story, is thick with superstition, especially the Indian superstition around The Monkey's Paw, a mummified monkey's paw brought from India to England. The person and owner who brings the paw is an ex-military officer, used to be posted in India. His name is Sergeant-Major Morris and he is a close friend to Mr. White, the head of a family consisting of Mr. White, Mrs. White, and Herbert White, their son. They live in a house named Laburnam Villa in a remote area with a very bad road and far from neighbours (Jacobs, 2019: 1).

To the remotely living family, Mr. Morris introduces the superstitious story concerning the mummified paw in his visit to this family. His story and the situation of the time of his visit "the night was cold and wet" (Jacobs, 2019: 1) enhances the superstition of the paw. The combination of darkness, coldness, and wetness of the situation creates a scary atmosphere.

To the enchanted audience, Morris who is talk active strongly warns the White family that the magical power of the paw is not a joke and should not be taken as a joke:

"It had a spell put on it by an old fakir," said the sergeant-major, "a very holy man. He wanted to show that fate ruled people's lives, and 
that those who interfered with it did so to their sorrow. He put a spell on it so that three separate men could each have three wishes from it." (Jacobs, 2019: 3).

The atmosphere is getting more gripping as Morris strongly believes that the magical power of the mummified paw is real as he solemnly says that the third wish of first owner of the paw is "for death" (Jacobs, 2019: 3). His reaction, as the second owner, when asked by Herbert White, the son, whether he has made the three wishes says: "II have," he said, quietly, and his blotchy face whitened" (Jacobs, 2019: 3). His facial expression indicated that his own experience is so terrifying that he, as a brave soldier, is scared.

However, Morris's scared reaction is ignored by the White family who is more curious than believing Morris's story. Their reaction is due to the routine, peaceful, but boring life they have for decades. Seeing that the White family takes interest on the paw, Morris decides to burn it: "suddenly threw it upon the fire. White, with a slight cry, stooped down and snatched it off" (Jacobs, 2019: 4). Mr. White's action indicates that he unconsciously wants to feel the thrilling experience implied in Morris' stories by not willing to lose the magic paw.

Seeing Mr. White's careless insistence, again Morris warns him seriously "I threw it on the fire. If you keep it, don't blame me for what happens. Pitch it on the fire again like a sensible man" (Jacobs, 2019: 4). Morris, who has a very bad experience with the paw, does not want to take any responsibility if the White family wants to keep it.

However, Mr. White's curious interest in the paw and its magical power is indicated by his wanting to know how to use it "Hold it up in your right hand and wish aloud," said the sergeant-major, "but I warn you of the consequences" (Jacobs, 2019: 4). Their playful action indicated by Mrs. White's joking wish makes Morris feel horribly concerned but helpless (Jacobs, 2019: 4).

Thus, the triggers of the playful choice later made by the White family, which will be discussed in the next session, is a combination of contextual elements; namely, the superstitious monkey's paw, curiosity, unbelieving the magical power, as well as playfulness out of routine life and remote living. These triggers which envelop the White family will finally flip their life over unexpectedly. In this case, the role of Mr. Morris and his story as well as the monkey's paw are to test humans' nature, whether or not they are tempted to follow unknown and dangerous path as an intermezzo in their boring life.

\section{Button, Button}

A brief general background of Matheson's short story entitled Button, Button will be presented to show the specific context leading to the choice made in a flash. If in Jacobs' Monkey's Paw the basic trigger is in the form of a mummified paw with magical power, in Matheson's Button, Button, the basic trigger is the mysterious box with a button attached to it. The mysterious box is suddenly laid near the front door of the Lewis' apartment with complete address (Matheson, p. 103).

The first person finding the box and taking it into the apartment is Norma Lewis, the wife of Arthur Lewis. The box also has a mysterious note "'Mr. Steward will call on you at 8:00 P.M" (Matheson, p. 103). When the person called himself $\mathrm{Mr}$. Steward comes according to the mentioned time, Norma who decides to 
open the door thinks that he is "a sales pitch" (Matheson, p. 103) and Norma does not want to let him in. However when he confirms Norma's words that the mysterious box is financially profitable and confirms Arthur that he does not try to sell anything, the couple lets him in.

The tension increases when the mysterious Mr. Steward tells them that "If you push the button," Mr. Steward told him, "somewhere in the world someone you don't know will die. In return for which you will receive a payment of $\$ 50,000 "$ (Matheson, p. 104). His enigmatic statement prompts different reactions triggered by different personal motives and personality. Arthur, a realistic and routine person, immediately does not like the idea in his statement at all and directly urges Mr. Steward to bring back his box, while Norma, also a realistic person but with big curiosity, tends to dig more information about the organization behind Mr. Steward. Seeing that one of the couple does not directly reject the challenging offering, Mr. Steward leaves his name card (Matheson, p. 105).

Thus the triggers of following the instruction to get $\$ 50,000$ or not are a mixture of the mysteriousness of the statement, the mysterious appearance of the box, and the mysterious appearance of Mr. Steward, and the personality of the potential clients. Like Mr. Morris in The Monkey's Paw, in Button, Button Mr. Steward and the mysterious box also serve to test the humans' personality whether or not they will be persuaded to take a challenging but mysterious choice.

\section{The Conflicts Surrounding the Careless Choices}

The choices finally done in response to certain lures are not free from conflicting responses. The conflicts might be subtly internal or strongly expressed. All these conflicts will be discussed in the following sub-section.

\section{The Monkey's Paw}

After Sergeant-Major Morris' leaving, the members of the White family are again alone but now with the mummified paw. They start talking about the paw, a new thing with its mysterious story that now enters their solitary life. Herbert, the son, young and full of life, does not take seriously the strong warning from Morris. He starts teasing her parents: "'Likely," said Herbert, with pretended horror. "Why, we're going to be rich, and famous and happy. Wish to be an emperor, father, to begin with; then you can't be henpecked" (Jacobs, 2019: 4). He is teasing the dominant position of the mother over the father. In his young mind, wealth and strong position can make her father more powerful than her mother.

However, Mr. White, being a simple man without many wishes, has no imagination what to ask for, since he feels that he has contented with his present life (Jacobs, 2019: 5). Seeing his father's reaction, young Herbert who is full of fun and jolly, playfully asks his father to try with the first wish: "If you only cleared the house, you'd be quite happy, wouldn't you?" said Herbert, with his hand on his shoulder. "Well, wish for two hundred pounds, then; that'll just do it"' (Jacobs, 2019: 5). Herbert gives a hint through the words "cleared the house" that the house 


\section{p-ISSN 1412-9418 e-ISSN 2502-5783 \\ Humanika Vol. 27 no 2 Copyright @2020 \\ Available online di http://ejournal.undip.ac.id/index.php/humanika}

they are living in now is not yet paid off, they still owe certain amount of money, around $\mathrm{f} 200$.

Playfully, because he does not believe the superstition, he asks his father to wish for that sum of money. The ritual for asking the first wish is done jokingly because Herbert dramatically plays piano to accompany his father wish: "II wish for two hundred pounds," said the old man distinctly" (Jacobs, 2019: 5). In this action, Herbert's playful choice with the consequence of getting $£ 200$ from the moral/ethical perspective can be classified as "Utilitarian Approach" in which the $f 200$ is not for Herbert personally, but for the sake of others too, particularly the sake of the whole family.

The wish, done playfully, immediately starts to spread its eeriness. The father, Mr. White, is shocked to death because: "It moved," he cried, with a glance of disgust at the object as it lay on the floor. "As I wished, it twisted in my hand like a snake" (Jacobs, 2019: 5). The docile father experiences an appalling experience in which the mummified paw contorts while he is uttering the words dictated by her son. However, the son and the mother disbelieve his personal experience because it is beyond reason. It is impossible for a mummified paw, an inanimate object, to be able to wriggle like a snake. Besides, the meek father tends to be slighted by the mother and son. A slight conflict begins to emerge in the used-to-be peaceful family. The triggers are the father's unbelievable personal experience versus the logical thinking of son and mother and the slighted position of the father in the family. Moreover, no money suddenly appears.

However, the eerie situation continues. This time in the form of the creepy atmosphere: "Outside, the wind was higher than ever, and the old man started nervously at the sound of a door banging upstairs. A silence unusual and depressing settled upon all three" (Jacobs, 2019: 5). The three of them, willingly or unwillingly, notice the different atmosphere at that time, however nobody utters a word about it. The father is the first family member who is affected by this grim situation while the son still throws a joke about the possibility of a sudden appearance of a sum of money that the father has wished.

Here, an internal conflict silently sneaks into each person's mind. When Herbert is alone in the living room after his parents go to bed, he starts seeing strange appearances ended with a horrible ape-like appearance in the dying fire in the fireplace. An internal conflict arises within the jovial Herbert, he begins to feel a bit nervous, as indicated when he accidentally touches the paw lying on the table: "His hand grasped The Monkey's Paw, and with a little shiver he wiped his hand on his coat and went up to bed" (Jacobs, 2019: 6). His jolliness disappears. He unconsciously feels that the paw is something horrible that should not be touched as indicated by his action of wiping his hand on his coat.

The eeriness still colors "the brightness of the wintry sun next morning" (Jacobs, 2019: 7). The fine weather of the winter season cannot drive away the creepiness of the situation. Herbert tries to ignore it and even still makes a joke about the money to his father "'Might drop on his head from the sky," said the frivolous Herbert" (Jacobs, 2019: 7) before leaving home to work. The mother at home is also a bit nervous although nothing special happens. The father is still influenced by the wriggling paw when he was making his first wish last night.

Thus, an internal conflict in the form of restless mind unconsciously permeates the members of the White 


\section{p-ISSN 1412-9418 e-ISSN 2502-5783 \\ Humanika Vol. 27 no 2 Copyright @2020 \\ Available daring di http://ejournal.undip.ac.id/index.php/humanika}

family. Night begins to descend and the jumpy mother notices that a stranger passes by in front of their house several times. Still remembers about the first wish and seeing the expensive dress of the stranger now opening their front gate, the mother curiously opens the door and greets the stranger (Jacobs, 2019: 8). From here on, the story rapidly leads on the unexpected turn.

\section{Button, Button}

The leaving of Mr. Steward does not stop the effect of his crazy statement on the Lewis family. Norma is apparently deeply influenced by the event. As a practical person with many plans involving monetary support, she still wants to talk about it but her husband is reluctant to respond. This is the seed of the conflict between husband and wife. Norma is described as very curious and intrigued and does not forget the offer of $\$ 50,000$ while Arthur, the husband, strictly says that "it's immoral" (Matheson, p. 106). As the husband is very strict in his principle, they go to sleep with conflicting ideas hanging in the night air.

Morning comes. Norma, on the way leaving the apartment to go to work, accidentally sees the card name of Mr. Steward that was torn by her husband the previous night. Unconsciously still keeping in her mind Mr. Steward's offer of $\$ 50,000$, she silently puts the pieces of card in her purse. The conflicting of unknown feelings haunting Norma the whole day at work. It is indicated by her unexplainable action, such as pasting together the torn pieces of the name card without knowing the real reason. She also cannot stop herself from the urge to call Mr. Steward to talk about the unknown victim for $\$ 50,000$. However when Mr. Steward explains further: "Exactly that," he answered. "It could be anyone. All we guarantee is that you don't know them. And, of course, that you wouldn't have to watch them die" (Matheson, p. 106), Norma considers it is as absurd and she angrily hangs up the phone.

Norma's opinion is unconsciously split into desiring the money and evaluating the consequence. In this vulnerable psychological condition, when she comes home, she sees again the mysterious box in front of the door. Her internal conflict is tensing between ignoring the box and taking the box inside the house. Finally what she considers a win-win solution is taken: "She put the package in a bottom cabinet. She'd throw it out in the morning" (Matheson, p. 107). Here it can be seen that Norma is indecisive, not like her husband. The offered money and the unknown victim are two important factors that make her hesitant.

While eating dinner together at home, Norma brings back the topic concerning the mysterious box and its mysterious offer. Norma is unconsciously still tempted with the money offer while the husband is still in his moral perspective and considers the action of pushing the button as a crime. His unwavering response is debated by Norma who does not feel that it is a big matter since she does not know the victim, while for the husband "The point is, Norma," he continued, "what's the difference whom you kill? It's still murder" (Matheson, p. 108). Here, Norma's husband strictly applies normative morality, he does not tolerate any killing under whatever reason since it is a forbidden sin, a murder.

Finally Norma blurts out what is imprinted in her mind all the time: "Fifty 
thousand dollars, Arthur," Norma interrupted. "A chance to take that trip to Europe we've always talked about ... "A chance to buy that cottage on the island" (Matheson, p. 108). Norma, on the other side, applies descriptive morality, her point of morality is situational, casuistic.

Thus, it can be summed up that the conflict between the husband and wife is triggered by Norma's orientation which is on the financial benefit justified by her descriptive morality while her husband's orientation is on the moral side strictly applying normative morality. The tensing argument that night finally ends with Arthur's polite but firm words "'I'd rather not discuss it anymore, if you don't mind" (Matheson, p. 108). Norma's husband's decision is not negotiable. The discussion is closed but apparently not settled.

The next morning Norma tries to redeem last night argument by making complete breakfast for her husband, Arthur. The situation becomes nice for a moment, however Norma begins to spoil it by, again, bringing up the subject of money from the offer and what she can do with that money: "That I'd like for us to go to Europe. Like for us to have a cottage on the island. Like for us to have a nicer apartment, nicer furniture, nicer clothes, a car. Like for us to finally have a baby, for that matter" (Matheson, p. 109). Here it can be detected that Norma insists on the benefit of that money for her especially and her husband because that sum of money can realize her dream plans, which she refers on behalf of the family.

Seeing that Arthur, her husband, is still strict with his normative moral perspective, the tempted Norma tries to remonstrate it by justifying the unknown reason behind the offer with her own assumption:

"I'm saying that they're probably doing it for some research project!" she cut him off. "That they want to know what average people would do under such a circumstance! That they're just saying someone would die, in order to study reactions, see if there'd be guilt, anxiety, whatever! You don't think they'd kill somebody, do you?!" (Matheson, pp. 109-110).

Norma's justification is to condone her own conflicting feeling, however Arthur, her husband steadfastly opposes it: "Arthur didn't answer. She saw his hands trembling. After a while, he got up and left" (Matheson, p. 110). Now his protest is not in the form of words again like before but in the form of gesture. It indicates that Arthur, whatever the reason, strongly disagree with Norma's inclination to consider the mysterious offer from the mysterious Mr. Steward with the mysterious international company behind it. Again, the conflict between Norma and her husband is closed but not settled.

Thus, it can be concluded that Norma's sidedness with the mysterious offer is classified as "The Egoistic Approach", because although she says it is on behalf of the family's long-term plans, actually underlying her statement is her own desire to realize her dream plans sooner through whatever means. Norma, obviously, does not pay much attention on the stated consequence because the victim is not her, or somebody she knows. Her self-centeredness and descriptive morality are so evident, whatever the reasons she tries to cover it.

Comparing The Monkey's Paw and Button, Button, it can be said that in both short stories there is money matter. However, in The Monkey's Paw, the sum of money proposed by the son is not for him alone but for the sake of the family, so it is classified as an action based on "Utilitarian 
Approach". Meanwhile, in Button, Button, the offered sum of money that makes the wife tempted is basically for the plans in which she will be greatly involved and enjoyed, thus it can be categorized as an action driven by "The Egoistic Approach".

\section{The Immediate, Natural, but Dreadful Consequences}

In this sub-section, the focus of discussion is on the quickness, naturalness, and terribleness of the wishes. The consequences will happen inevitably and unexpectedly as shown below with certain similarities and differences.

\section{The Monkey's Paw}

Sergeant-Major Morris, the second owner of the mummified monkey's paw, has warned the White family several times about the consequences of making wishes to the paw. Mr. White, the father, repeats his words to the mother: "Morris said the things happened so naturally," said his father, "that you might if you so wished attribute it to coincidence" (Jacobs, 2019: 7). "Naturally" and "Coincidence" are the key words referring to the granting of the wishes.

The naturalness combined with coincidence prove to be deathly shocking. The stranger on the front gate turns out to be their unexpected guest. $\mathrm{He}$ is a representative from the "Maw and Meggins" where Herbert works (Jacobs, 2019: 8) and he awkwardly informs Mr. and Mrs. White that Herbert, their son is "'Badly hurt," he said, quietly, "but he is not in any pain"' (Jacobs, 2019: 8). The parents are shell shocked after realizing the meaning of the guest's words, that is, Herbert, their dear son, has died in the factory accident "He was caught in the machinery" (Jacobs, 2019: 9). Actually, it can be classified as natural although terrible accident at work if not related to the grim story of the monkey's paw.

Their devastating shock has not ended. When in an awkward situation the representative of the company says that the company "wish to present you with a certain sum as compensation" (Jacobs, 2019: 9) the parents get another horrid realization. The father helplessly, disbelievingly, devastatingly, but curiously, asks the sum of the compensation bearing in mind the horrible first wish he has made dictated by his son. The direct answer "Two hundred pounds" (Jacobs, 2019: 9) makes both of them unable to bear the shocks anymore: "Unconscious of his wife's shriek, the old man smiled faintly, put out his hands like a sightless man, and dropped, a senseless heap, to the floor" (Jacobs, 2019: 9). Thus, the consequence of their first wish comes immediately in the form of a natural crushing coincidence.

Actually, there is a foreshadowing in Herbert's words when he is teasing his father after the father makes the first wish of $£ 200$ to settle the payment of their house: "“Well, I don't see the money," said his son as he picked it up and placed it on the table, "and I bet I never shall"'" (Jacobs, 2019: 5). Herbert's words "and I bet I never shall" foreshadow the coming fact that Herbert literally will not see the money since it is the compensation of his fatal accident in the factory. The naturalness, however shocking, of the granting of the first wish is already set when the son in a joking attitude dictated his father to make the first wish. 


\section{Button, Button}

Norma, left behind by her husband who goes to work, is in a defiant mood. Angry that her opinion is strongly opposed by her husband, Norma tries to find an outlet for her dissatisfaction: "I'm going to be late, she thought. She shrugged. What difference did it make? She should be home, anyway, not working in an office" (Matheson, p. 110). She begins to feel unfair that she has to work, implying that if they have enough money she may stay at home and have a leisure time.

In this moody feeling haunted by dissatisfaction and disappointment, Norma takes the mysterious box that she previously places in the bottom cabinet. After a moment of thinking she decides to do the following action:

taking the key from its envelope and removing the glass dome. She stared at the button ....

Reaching out, she pressed it down. For us, she thought angrily.

She shuddered. Was it happening? A chill of horror swept across her (Matheson, p. 110).

Norma finally presses the button. Her justification of her action is stated in the words "For us". Her anger of her husband's strong refusal dominates her mind. So, she finally, without her husband's knowledge, takes the mysterious offer and its risk that she does not really care since she, in her egoistic thought, does not know the person. However, deep down in her heart, for a swift of moment, there is a hidden fear of the consequence indicated by the words "A chill of horror swept across her". Since there is no immediate happening, she feels like being fooled and she roughly throws the button box in the waste basket and goes to work (Matheson, p. 110). Nothing happens after that.

While preparing supper and waiting for her husband returning home from his work, suddenly the phone rings:

"This is the Lenox Hill Hospital."

She felt unreal as the voice informed her of the subway accident-the shoving crowd, Arthur pushed from the platform in front of the train. She was conscious of shaking her head but couldn't stop.

As she hung up, she remembered Arthur's life-insurance policy for $\$ 25,000$, with double indemnity for- (Matheson, p. 110).

The stated consequence that someone somewhere will die is immediately fulfilled, and in line with that, as promised Norma gets $\$ 50,000$. In other words, Norma gets what she wants, the $\$ 50,000$ that she silently longs and hotly argues with her husband. The accident befallen her husband is so natural, a rare accident on the railway station but possible to happen, that Norma cannot say it is deliberately conspired.

As an outlet for the conflicting feelings in her heart: guilt, confusion, feeling cheated, desperation, she smashes the mysterious box with its button. However, she finds out that inside the box, there is nothing, except the button: "There were no transistors in the box, no wires or tubes. The box was empty" (Matheson, p. 110). The box is really mysterious, as mysterious as the offer and its risk.

It can be said that in both short stories the consequence is similar, that is in the form of death. However in The Monkey's Paw, the death consequence is not directly and verbally stated as in Button, Button. Another similarity is that the consequence occurs immediately, within 
24 hours. In The Monkey's Paw the wish is uttered at night and the son's deadly accident is the next day around noon while in Button, Button the wish is stated in the morning and the husband's deadly accident is in the early evening. The differences are in the victim and the origin of the money. In The Monkey's Paw the victim is the initiator, that is the son, and the sum of money is the compensation of the accident, while in Button, Button the victim is not the initiator and the sum of money is the life insurance of the victim.

\section{The Twisted Endings}

Both short stories, The Monkey's Paw and Button, Button, are full of suspense leading to tragic events. One of the tools to support suspense is by using twisted plot. In the two short stories, the use of twisted ending makes the stories startling and unforgettable.

\section{The Monkey's Paw}

The short story by W.W. Jacobs entitled The Monkey's Paw does not end with the tragic death of Herbert. More unexpected but horrid events follow. After the funeral, numbed by deep sadness and horror, the parents are silent and hopeless for several days. However, this situation is actually like a time bomb, the explosion is upcoming.

One night, the silent and devastated mother suddenly has a shocking idea. Remembering that they still have two more wishes, the mother crazily insists that they use those opportunities to "wish our boy alive again" (Jacobs, 2019: 11). The father, more sensible than the wife, tries to prevent her crazy intention: "He has been dead ten days, and besides he-I would not tell you else, but-I could only recognize him by his clothing. If he was too terrible for you to see then, how now?" (Jacobs, 2019: 11). The husband's sensible information cannot deter the grieving mother's strong will. The mother is beyond logic driven by her crippling loss and hopeless sadness. Because the mother is dominant over the father, her insistence forces the refusing father to say the second wish: "He raised his hand. "I wish my son alive again"'" (Jacobs, 2019: 12). Again, the father is dictated to make a wish.

The darkness of the winter night envelops the old figures, the female one is full of unreasonable hope while the male one is full of helpless fear. Time is dragging. Both of them are unable to sleep for different reasons. A sound of mysterious knocking makes them jump. The father, immediately guessing the meaning of the knocking, tries to deceive his wife by saying that it is the sound of a rat (Jacobs, 2019: 12), however the next successive knocking sounds that are getting louder and louder in the middle of the silent winter night cannot deceive his wife anymore.

Crazily hopeful, the mother tries to run into the door while the father tries to hold her still: "“For God's sake don't let it in," cried the old man, trembling" (Jacobs, 2019: 13). Here, the sensible father uses the pronoun "it", not "him" to refer to whoever/whatever knocking at the door. The father uses inanimate pronoun "it" because he knows that his son is dead and whoever knocking at the door is inanimate figure, badly mutilated and has been buried for ten days.

The insane power of the mother is beyond any restraint, so in the total darkness inside the house she tries to open the door, luckily its bolt is too high for her to reach and she needs a chair to stand for. The time between the mother's dragging a chair and opening the bolt is used by the 
terrified father to desperately find the mummified paw lying somewhere in the darkness inside the room. The time is critical: "He heard the creaking of the bolt as it came slowly back, and at the same moment he found The Monkey's Paw, and frantically breathed his third and last wish" (Jacobs, 2019: 13). At the last dire second, the panic-stricken father is able to find the mummified paw and null the second wish ordered by his wife in his third and last wish.

The effect of the third and last wish, again, is immediate:

The knocking ceased suddenly, although the echoes of it were still in the house. He heard the chair drawn back, and the door opened. A cold wind rushed up the staircase, and a long loud wail of disappointment and misery from his wife gave him courage to run down to her side, and then to the gate beyond. The street lamp flickering opposite shone on a quiet and deserted road (Jacobs, 2019: 13).

The knocking and whoever doing the knocking mysteriously vanish soon after the last wish is desperately uttered by the sensible father. Thus, all three wishes have been uttered, and the consequences have immediately realized. The twisted ending in the last minute is successful to grip the readers' attention with horrid guessing alluding to the resurrection of the badly mutilated body of the son before knowing the last happening.

\section{Button, Button}

The short story by Richard Matheson entitled Button, Button does not stop with the telephone call informing the railway accident. There is another telephone call that startles Norma. It is from the mysterious Mr. Steward. Hearing his voice, Norma, screaming loudly, asks the question haunting her mind after hearing the death of her husband: "You said I wouldn't know the one that died!" (Matheson, p. 111). Norma utterly never imagines that the victim will be her own husband because she blindly holds on the promise that she does not know the victim.

Previously in her debate with her husband she persuasively says: "If it's some old Chinese peasant ten thousand miles away? Some diseased native in the Congo" (Matheson, p. 108). Norma blindly thinks that the victim will be a person in a faraway places. From her words Norma's personality can be seen. Not only is she egoist, she is also racist, she does not care if the victim is a Chinese or a person in Congo in certain condition. Norma only thinks of the benefit for herself.

As in The Monkey's Paw, the incoming suspense in Button, Button is cleverly weaved in a twisted ending. Norma's question and the question of the readers too, is brilliantly answered by $\mathrm{Mr}$. Steward: "My dear lady," Mr. Steward said. "Do you really think you knew your husband?" (Matheson, p. 111). Norma is stunned by this thought-provoking question calmly uttered by Mr. Steward. Mr. Steward's answer in the form of question also deconstructs the common perception of "knowing someone". Mr. Steward's answers opens a deeper meaning of "knowing someone", it is not simply physical closeness like being a spouse, or close members of the family, or close friends. Norma in this perspective does not know her husband at all. If she "knows" him, she will not argue with him incessantly about pushing the button to get the money. An egoist person like Norma will not be able to "know" someone 
even though that someone is physically very close to her for years.

Thus, both twisted endings have the role to dig out the hidden personality of the closely connected characters. In The Monkey's Paw, the "henpecked" husband is more reasonable than the dominating wife. The father realizes the appalling horror of resurrecting the already buried mutilated body of the son but the mother, totally blinded by lost love and devastating grief, legalizes any means to make her impossible intention materialized. In Button, Button, the twisted ending emphasizes the egoistic side of the wife and her inability to consider the other perspective results in the death of a moralistic husband for a sum of money that the wife wants to realize her luxurious dreams.

\section{Conclusions}

The short story entitled The Monkey's Paw by W.W. Jacobs and Button, Button by Richard Matheson talk about free choices upon decided consequences. No choices are free from consequences. Whatever the reasons underlying the choices, the obviously stated consequences will immediately materialize in unexpected but natural ways.

If The Monkey's Paw is dominated by superstition and verbal jokes driven by disbelief about the magical but evil power, Button, Button is dominated by a hanging mystery and a long, hot argument about the stated consequence. The specific situation in each short story leads to a specific free choice taken. In The Monkey's Paw the witty son jokingly asks the father to wish for a sum of money to settle the shortage of home payment so that his parents will be free from the payment burden, while in the Button, Button the self-centered wife in the peak of her annoyance over the unsettled hot argument with her moralistic husband makes her own decision justifying it on behalf of their benefit instead of hers.

However, in both short stories the element of suspense is so strong and gripping, especially in the last page. The Monkey's Paw ends with everything that is back to normal according to the law of death after the horrible attempt to resurrect the dead body of the son, while Button, Button ends with a question that opens for a deep contemplation concerning something often taken for granted; namely the notion of knowing someone. Both short stories also portrays human personality, that is, humans are easily entrapped in making free choices although the warning about the appalling consequences has been stated implicitly or explicitly, beforehand. The hidden reason behind each free choice indicates the utilitarian or the egoistic nature of the person who dictates the choice, as in The Monkey's Paw or who decides to choose as in Button, Button.

\section{References}

Beard, Adrian. (2001). Texts and Contexts. Introducing literature and language study. London: Routledge.

Remak, Henry H. (1961). Comparative Literature, Its Definition and Function. Comparative Literature: Method and Perspective. Stallknecht, Newton P. and Frenz, Horst (eds.). Kingsport, Tenn.: Kingsport Press, Inc., pp. 3-37 
Krosch, Amy R.; Figner, Bernd; Weber, Elke U. Choice processes and their post-decisional consequences in morally conflicting decisions. Judgment and Decision Making, Vol. 7, No. 3, May 2012, pp. 224-234.

Bonde, et all. (2013). Making Choices: a Framework for Making Ethical Decisions. Retrieved from https://www.brown.edu/acade mics/science-and-technologystudies/framework-makingethical-decisions accessed May 18, 2020.

Hill, Chazda. (2017). The 10 Types of Plot Twists. Retrieved from http://greatstorybook.com/10types-plot-twists/ accessed May 23, 2020

Gert, Bernard. (2020). The Definition of Morality. Stanford Encyclopedia of Philosophy. https://stanford.library.sydney. edu.au/archives/sum2002/entri es/morality-definition/accessed November 28, 2020

Jacobs, W.W. (2019). The Monkey's Paw. global greybooks.com.
Levin, Jonathan and Milgrom, Paul. (2004). Introduction to Choice Theory.

(https://pdfs.semanticscholar.o $\mathrm{rg} / 06 \mathrm{cb} / 6027 \mathrm{bfbb} 124 a 0 \mathrm{e} 4 \mathrm{ce} 84$ 52cc9e81953f6e88d.pdf?_ga=2. 208116370.1853672167.15902 41160-309920756.1590241160 accessed May 23, 2020)

Mateson, Richard. Button, Button. http://jhampton.pbworks.com/ w/file/fetch/47378440/button accessed May 13, 2020. Pp. 103 111

The Nature of Morality and Moral Theories. Retrieved from http://home.sandiego.edu/ ba ber/gender/MoralTheories.htm I accessed May 21, 2020 https://www.britannica.com/biogr aphy/ W-W-Jacobs accessed May 21, 2020.

https://www.britannica.com/biogr aphy/Ri chard-Matheson accessed May 21, 2020). 